\section{Generating a Unique Germplasm Base for the Breeding of Day-neutral Strawberry Cultivars}

\author{
James F. Hancock ${ }^{1}$, Patrick P. Edger, and Peter W. Callow \\ Department of Horticulture, Michigan State University, East Lansing, MI \\ 48824
}

Thomas Herlache
MSU Technologies, Michigan State University, East Lansing, MI 48823

Chad E. Finn

U.S. Department of Agriculture, Agricultural Research Service, Northwest Center for Small Fruit Research, Corvallis, OR 97330

Additional index words. day-neutral, Fragaria $\times$ ananassa, Fragaria virginiana, Fragaria chiloensis

Royce S. Bringhurst and Victor Voth at the University of California-Davis (UCDavis) revolutionized the strawberry industry in 1979 with the release of their first "dayneutrals" 'Aptos', 'Brighton', and 'Hecker' (Bringhurst and Voth, 1980). These dayneutrals could be programmed to produce fruit 3 months after planting and continued to fruit for up to 5 months regardless of daylength, greatly expanding the production season in California.

These unique cultivars were generated by backcrossing for three generations to conventional short-day types from a hybrid Bringhurst made between 'Shasta' and a Fragaria virginiana subsp. glauca clone from the Wasatch Mountains in Utah. Bringhurst continued backcrossing his elite day-neutral selections annually, releasing the very successful 'Selva' from the fourth generation and 'Seascape' from the fifth. This same strategy has been continued by Bringhurst's replacements resulting in a string of dayneutral cultivar releases from the UC-Davis program.

As word spread about Bringhurst's accomplishments, it did not take worldwide strawberry breeders long to begin using his day-neutral germplasm to generate new repeat flowering types. The standard approach was to hybridize a UC-Davis day-neutral selection or cultivar with their local shortday selections and then backcross like Bringhurst had done into their local breeding population. The USDA's 'Tristar' and 'Tribute' were the first day-neutrals to be released outside of California in 1981. They were generated by Donald Scott in a 1974 cross using the parent of 'Brighton' and 'Hecker' —Cal. 65.65-601 (Draper et al., 1981).

Received for publication 2 Jan. 2018. Accepted for publication 1 May 2018.

${ }^{1}$ Corresponding author. E-mail: hancock@msu. edu.
Over the last few decades, several dayneutral cultivars have been developed outside of California using Bringhurst's source of day-neutrality, but none of these has achieved the commercial success of the UC-Davis cultivars. In general, their fruit are softer and smaller, and their floral development is inhibited by the hot summer temperatures common in temperate climates (Hancock et al., 2008). Because temperature has such a strong impact on performance, we have suggested that the day-neutrals are more appropriately called remontant (Bradford et al., 2010).

To facilitate the development of remontant cultivars outside of California, it is likely that local germplasm bases must be expanded. Levels of future success may be tied to incorporating new genetics into local breeding programs that are unique to the UC-Davis germplasm base. It might also be beneficial to incorporate genes specifically from genotypes that are known to be heat tolerant. Herein, we describe our efforts to generate such a diverse population that we would like to share with the breeding community.

\section{Origin and Development}

Our germplasm development work progressed in three stages. In the Stage 1, we crossed a set of the most widely planted North American cultivars and native $F$. virginiana with UC-Davis 'Hecker', 'Seascape', 'Selva', and 'Chandler'. A list of the native and cultivar parents can be found in Hancock et al. (2002). We also hybridized eastern cultivars with USDA-ARS selections developed by coauthor C.E. Finn containing blends of elite Pacific Northwestern selections, native germplasm, and California cultivars. The California cultivars were 'Aromas' and 'Camarosa' and the native selections were $F$. virginiana from Montana and Minnesota, and a land race of Fragaria chiloensis from Ecuador (Finn et al., 1998).
Most of the native selections that we used as parents are included in what was named the "Supercore Collection" (Hancock et al., 2000) and deposited in the National Clonal Germplasm Repository (NCGR) in Corvallis, OR. This collection is composed of 38 wild strawberry accessions that are horticulturally superior and represent a considerable range of the natural diversity found in the octoploids $(2 n=8 x=56) F$. chiloensis and $F$. virginiana (Hancock et al., 2000, 2001a, $2001 \mathrm{~b}$ ). It was based on evaluations of more than 2500 native $F$. virginiana from across the United States and Canada and more than $6000 \mathrm{~F}$. chiloensis from California, Chile, and the Pacific Northwest.

In Stage 2 of our germplasm development, we hybridized the most elite selections from Stage 1 with four remontant Fragaria xananassa genotypes known to be heat tolerant (able to readily initiate flowers at $26^{\circ} \mathrm{C}$ or higher). We took two approaches to identify and incorporate greater heat tolerance into our breeding population. In the first, we screened 13 cultivars and wild selections for their ability to flower and runner across a range of temperatures from 18 to $30{ }^{\circ} \mathrm{C}$ (Serçe and Hancock, 2005). We found the old Wyoming cultivar Fort Laramie to be much more heat tolerant than any other of the screened genotypes. We also compared the heat tolerance of the popular Midwestern cultivar Honeoye to the remontant 'Tribute' and found it to be more heat tolerant at $26^{\circ} \mathrm{C}$ (Bradford et al., 2010). We then generated a segregating population of 'Tribute' $\times$ 'Honeoye' $(\mathrm{T} \times \mathrm{H})$ and selected the most heat-tolerant individuals to use as parents (Mookerjee et al., 2013).

In our Stage 3 of germplasm development, we hybridized our most promising remontant selections from the first two stages of crosses with elite $F_{2}$ selections from the $F$. ×ananassa "reconstruction" project (Hancock et al., 1993, 2010; Stegmeir et al., 2010). We also intercrossed most of the elite $\mathrm{F}_{2}$ hybrids identified in that project. In the reconstruction work, 10 elite wild and cultivated $F$. chiloensis and 16 native $F$. virginiana were first intercrossed within species, and then the most promising hybrids were crossed between species. An effort was made to incorporate as much geoecological diversity of each species as possible. Most of the original parents were represented in the Supercore Collection.

The hybrid families generated in 2013 and 2015 were planted in groups of 20-25 together in rows at $1.2 \mathrm{~m} \times 1.2 \mathrm{~m}$ spacing at the Southwestern Michigan Research and Extension Center (Benton Harbor, MI) in late May in 2014 and 2016. In an adjacent field were planted 'Seascape' and 'Albion'. The first round of flowers was removed from each plant and any runners that emerged were trained by cross row cultivation into $1 \times$ $1 \mathrm{~m}^{2}$ squares. Starting in mid-July, the plantings were evaluated weekly to identify superior genotypes until all flowering was significantly diminished in September. Subjective notes (1-10) were taken on the most elite 


\begin{tabular}{|c|c|c|c|c|c|c|c|c|c|c|c|}
\hline \multirow[b]{2}{*}{ MSU ID } & \multirow[b]{2}{*}{ PI number } & \multirow[b]{2}{*}{ CFRA } & \multirow[b]{2}{*}{ Other ID } & \multirow[b]{2}{*}{ Cross } & \multicolumn{7}{|c|}{ Composition } \\
\hline & & & & & EST SD & EST RM & CA SD & CA RM & PNW SD & $F \mathrm{c}$ & $F_{\mathrm{V}}$ \\
\hline Redstart & & & MSU 67 & 'Honeoye' $\times$ 'Chandler' & 50 & 0 & 50 & 0 & 0 & 0 & 0 \\
\hline Wasatch & & & MSU 68 & 'Seascape' × MSU 38 & 25 & 25 & 0 & 50 & 0 & 0 & 0 \\
\hline MSU 75 & 686943 & 2302 & MI 13-1-42 & MSU $25 \times$ MI 10-24-52 & 25 & 50 & 0 & 25 & 0 & 0 & 0 \\
\hline MSU 76 & 686944 & 2303 & MI 13-5-14 & MSU $61 \times$ TH 9-16-5 & 25 & 50 & 12.5 & 0 & 6.25 & $6.25^{z}$ & 0 \\
\hline MSU 77 & 686945 & 2304 & MI 13-6-18 & MSU 21 × MI 10-24-52 & 0 & 50 & 25 & 25 & 0 & 0 & 0 \\
\hline MSU 79 & 686946 & 2305 & MI 13-12-69 & MI 8-66-47 × TH 9-16-26 & 37.5 & 37.5 & 0 & 25 & 0 & 0 & 0 \\
\hline MSU 82 & 686947 & 2306 & MI 13-12-70 & MI 8-66-47 × MI 10-11-32 & 25 & 12.5 & 0 & 50 & 0 & 0 & $12.5^{\mathrm{y}}$ \\
\hline MSU 83 & 686948 & 2307 & MI 13-16-52 & MI 8-27-73 × TH 9-16-26 & 25 & 37.5 & 0 & 31.25 & 0 & 0 & 6.25 \\
\hline MSU 84 & 686949 & 2308 & MI 13-17-43 & 'Seascape' $\times$ MI 10-11-32 & 12.5 & 0 & 0 & 75 & 0 & 0 & $12.5^{\mathrm{y}}$ \\
\hline MSU 85 & 686950 & 2309 & MI 15-16-31 & FVC 11-58 × 'Redstart' & 25 & 0 & 25 & 0 & 0 & $25^{\mathrm{w}}$ & $25^{\mathrm{v}}$ \\
\hline MSU 86 & 686951 & 2310 & MI 15-22-26 & MSU $70 \times$ MSU 73 & 25 & 12.5 & 0 & 56.25 & 0 & 0 & $6.25^{\top}$ \\
\hline MSU 87 & 686952 & 2311 & MI 15-35 (2) & 'Redstart' $\times$ TH 9-16-26 & 50 & 25 & 25 & 0 & 0 & 0 & 0 \\
\hline MSU 88 & 686953 & 2312 & MI 15-7-41 & FVC $16-1 \times$ FVC $11-58$ & 0 & 0 & 0 & 0 & 0 & $50^{\mathrm{u}}$ & $50^{t}$ \\
\hline MSU 89 & 686954 & 2313 & MI 15-19-11 & FVC $10-2 \times$ FVC $8-1$ & 0 & 0 & 0 & 0 & 0 & $50^{\mathrm{s}}$ & $50^{\mathrm{r}}$ \\
\hline MSU 90 & 686955 & 2314 & MI 15-21-2 & FVC $28-1 \times$ FVC $8-1$ & 0 & 0 & 0 & 0 & 0 & $50^{\mathrm{s}}$ & $50^{\mathrm{t}}$ \\
\hline
\end{tabular}

${ }^{\mathrm{z}}$ Ecuador.

${ }^{\mathrm{y}}$ Minnesota.

${ }^{\mathrm{x}}$ Montana.

${ }^{\mathrm{w}}$ California and Chile.

${ }^{\mathrm{v}}$ Montana and Ontario.

${ }^{\mathrm{u} B}$ British Columbia, California, and Chile.

${ }^{\mathrm{t}}$ Minnesota, Montana, and Ontario.

${ }^{\mathrm{s}}$ California, Chile, and Ecuador.

${ }^{\mathrm{r}}$ Minnesota and Montana.

EST SD = eastern short-day cultivars; EST RM = eastern remontant cultivars; CA SD = California short-day cultivars; CA RM = California remontant cultivars; PNW SD = Pacific Northwest short-day cultivars; Fc = native Fragaria chiloensis; Fv = native Fragaria virginiana .

selections for season, productivity, vigor, fruit size, appearance, firmness, internal and external color, and flavor.

\section{Horticultural Characteristics}

Well-adapted, elite hybrids were recovered from all our various crossing endeavors (Tables 1 and 2). Eleven hybrids were selected from crosses of our elite breeding material and UC-Davis cultivars and two of these have been released as cultivars (Redstart and Wasatch). Details on the two cultivar releases can be found at http://msut. technologypublisher.com/technology/22785 and http://msut.technologypublisher.com/ technology/22786. Wasatch is a strong remontant and likely inherited this trait from its parent 'Seascape', containing the Wasatch source of remontancy. Redstart is a weak remontant and was derived from a cross of two short-day cultivars, Chandler and Honeoye. In the MSU breeding program, both these two short-day types have been found to produce a small percentage of remontant progeny.

From the Stage 2 crosses, we selected three hybrids with heat-tolerant $\mathrm{T} \times \mathrm{H}$ in their background (MSU 79, 83, and 87), two with 'Fort Laramie' (MSU 75 and 77), four with $F$. virginiana (MSU 82, 83, 84, and 86), and one with $F$. chiloensis (MSU 76). MSU 83 combines genes from $F$. virginiana and heat-tolerant $\mathrm{T} \times \mathrm{H}$. The origins of the $F$. virginiana contributors were Minnesota $(\mathrm{RH}$ 30) and Montana (LH 50-1), whereas the $F$. chiloensis donor was from Ecuador. The Ecuador contributor entered through one of C.E. Finn's complex hybrids with California and Pacific Northwestern germplasm in its background.

Table 2. Pedigrees of the parents of elite remontant MSU strawberry selections.

\begin{tabular}{|c|c|}
\hline ID & Parents \\
\hline Del Norte & wild Fragaria chiloensis subsp. lucida from California (CFRA 38; PI 551449) \\
\hline Frederick 9 & $\begin{array}{l}\text { wild Fragaria virginiana subsp. virginiana from Ontario } \\
\text { (CFRA 1695; PI 612493) }\end{array}$ \\
\hline FVC 8-1 & $($ Scotts Creek $\times$ NAH 3$) \times($ RH $30 \times$ LH 50-4) \\
\hline FVC $10-2$ & $(\mathrm{NAH} 3 \times$ MAR $1 \mathrm{~A}) \times(\mathrm{RH} 30 \times$ LH 50-4) \\
\hline FVC 11-58 & $($ Frederick $9 \times$ LH 50-4) $\times($ Scotts Creek $\times$ MAR 1A $)$ \\
\hline FVC 16-1 & $\begin{array}{l}{[(\text { Sable Beach } 1 \times \text { Del Norte }) \times(\text { Lighthouse } 3 \times \text { Del Norte })] \times} \\
\quad(\text { Montreal } 10 \times \text { RH } 23)\end{array}$ \\
\hline FVC 28-1 & $(\mathrm{HM} 1 \times \mathrm{NAH}) \times(\mathrm{RH} 30 \times \mathrm{MR} 10)$ \\
\hline NAH 3 & wild $F$. chiloensis f. chiloensis from Huachi, Ecuador (CFRA 1480; PI 612318) \\
\hline Lion's Head 3 & wild $F$. chiloensis subsp. pacific from British Columbia \\
\hline LH 50-4 & wild $F$. virginiana subsp. glauca from Montana (CFRA 1697; PI 612495) \\
\hline MAR 1A & wild F. chiloensis f. patagonica from Chile (CFRA 1075; PI 602567) \\
\hline MI 07-34 & 'Tribute' $\times$ ORUS 2461 \\
\hline MI 8-27-73 & 'Seascape' $\times$ MSU 07-34 \\
\hline MI 8-66-47 & 'Seascape' $\times$ MSU 38 \\
\hline MI 10-11-32 & 'Selva' $\times$ MSU 5 \\
\hline MI 10-24-52 & 'Seascape' $\times$ 'Fort Laramie' \\
\hline Montreal River 10 & wild $F$. virginiana subsp. virginiana from Ontario (CFRA 1699; PI 612497) \\
\hline MSU 5 & RH $30 \times$ 'Honeoye' \\
\hline MSU 21 & 'Tribute' $\times$ 'Chandler' \\
\hline MSU 25 & 'Tribute' $\times$ 'Allstar' \\
\hline MSU 38 & 'Tribute' $\times$ 'Honeoye' \\
\hline MSU 61 & 'Tribute' × ORUS 2264 \\
\hline MSU 70 & 'Seascape' × MI 07-34 \\
\hline MSU 73 & 'Earliglow' $\times$ 'Seascape' \\
\hline ORUS 2063-1 & 'Redcrest' $\times$ NAH 3 \\
\hline ORUS 2264-1 & 'Camarosa' × ORUS 2063 \\
\hline ORUS 2461-1 & 'Aromas' × LH 50-4 \\
\hline RH 23 & wild $F$. virginiana subsp. virginiana from Minnesota (CFRA 1700; PI 612498) \\
\hline RH 30 & wild $F$. virginiana subsp. virginiana from Minnesota (CFRA 1701; PI 612499) \\
\hline Sable Beach 1 & wild $F$. chiloensis subsp. pacifica from British Columbia \\
\hline Scotts Creek & wild $F$. chiloensis subsp. pacifica from California (CFRA 1692; PI 61690) \\
\hline TH 9-16-26 & 'Honeoye' $\times$ 'Tribute' \\
\hline
\end{tabular}

From the Stage 3 crosses, three selections were made that were composed of only wild derived genes (MSU 88, 89, and 90) and another one that had half of its genes from wild sources (MSU 85). These selections combine genes in multiple combinations of F. chiloensis from British Columbia, California,
Chile, and Ecuador and $F$. virginiana from the locations Ontario, Minnesota (2), and Montana.

In general, the selections performed favorably compared with 'Albion' and 'Seascape' (Table 3). All except 'Redstart' appeared to be strong remontants, flowering 
Table 3. Performance of MSU elite remontant selections at the Southwest Michigan Research and Extension Center, Benton Harbor, MI. Ratings: 1 (poor) to 10 (excellent).

\begin{tabular}{llllccccc}
\hline ID & Vigor & Yield & Size & Appearance & Internal color & $\begin{array}{c}\text { External } \\
\text { color }\end{array}$ & Firmness & Flavor \\
\hline Albion & 6.7 & 7 & 9 & 8 & 6.5 & 7.7 & 9.7 & 8 \\
Seascape & 7.2 & 7.5 & 6 & 8 & 8 & 8.5 & 8.2 & 6.5 \\
Redstart & 8 & 8 & 6.5 & 8 & 7 & 7.7 & 7.7 & 7.7 \\
Wasatch & 8.2 & 8.7 & 7 & 7.5 & 7.5 & 8.2 & 8.2 & 8 \\
MSU 75 & 9.5 & 8 & 8.0 & 8 & 8 & 8 & 7.5 & 7 \\
MSU 76 & 9 & 8 & 7.7 & 7.5 & 8 & 7.5 & 7.2 & 6 \\
MSU 77 & 9.5 & 9.5 & 6 & 8 & 7.5 & 6 & 6 & 6 \\
MSU 79 & 7 & 8 & 8 & 8 & 7.5 & 6 & 7 & 6 \\
MSU 82 & 8 & 9 & 6.5 & 6 & 8 & 7.5 & 8 & 8 \\
MSU 84 & 8 & 8 & 6 & 7.5 & 7.5 & 8 & 7 & 7 \\
MSU 85 & 9.5 & 8 & 7 & 7.5 & 7.5 & 7.5 & 7.5 & 7.5 \\
MSU 86 & 8 & 8 & 8 & 7.5 & 7.5 & 7.5 & 7 & 7 \\
MSU 87 & 9.5 & 9.5 & 7 & 8 & 8 & 8 & 5 & 7 \\
MSU 88 & 8 & 7.5 & 7.5 & 7.5 & 6 & 6 & 6 & 9 \\
MSU 89 & 8 & 7.5 & 7 & 7.5 & 7.5 & 8 & 6 & 7 \\
MSU 90 & 8 & 8 & 7 & 7.5 & 7.5 & 8 & 6 & 7 \\
\hline
\end{tabular}

well into September. 'Albion' fruit were larger and firmer than the fruit of any of the selections, but all of the hybrids had higher yields, vigor, and more internal color than Albion. 'Seascape' was firmer and had better external color than all the selections except 'Wasatch', but most of the hybrids were superior to 'Seascape' for vigor, yield, size, and flavor.

\section{Summary and Availability}

Through these efforts, we believe we have constructed a unique breeding population for developing new remontant strawberry cultivars. We have successfully mixed cultivars from California, the eastern United States, and the Pacific Northwest with genes from native $F$. virginiana and $F$. chiloensis.

These four native $F$. virginiana selections could carry genes for day-neutrality that are unique from those of Bringhurst's Wasatch selection. LH 50-4 is in the same Rocky Mountain subspecies (subsp. glauca) as the Wasatch selection, but the other three, RH 23, RH 30, and Montreal River 10, are all in a different, eastern subspecies (subsp. virginiana). We brought an old heat-tolerant cultivar (Fort Laramie) into the mix along with a genotype from a hybrid family of $F$. xananassa specifically screened for heat tolerance. 'Fort Laramie' was likely developed using $F$. virginiana subsp. glauca that is also unique to the Wasatch selection (Hildreth and Powers, 1940; Powers, 1954).

Time will tell if this breeding population will meet expectations, but if genetic diversity is the key to breeding success, this population should be useful to many strawberry breeders. Clones of these MSU selections have been deposited into the U.S. NCGR at Corvallis, OR, for research use. Seasonally available plant materials such as runners, leaves, pollen, or other forms can be requested through GRIN-Global at https://npgsweb.ars-grin.gov/ gringlobal/search.aspx? or by communicating with the Curator, Dr. Kim Hummer.

\section{Literature Cited}

Bradford, E., J.F. Hancock, and R.M. Warner. 2010. Interactions of temperature and photoperiod determine expression of repeat flowering in strawberry. J. Amer. Soc. Hort. Sci. 135:102-107.

Bringhurst, R.S. and V. Voth. 1980. Six new strawberry varieties released. Calif. Agr. February, p. 12-15.

Draper, A.D., G.J. Galletta, and H.J. Swartz. 1981. 'Tribute' and 'Tristar' everbearing strawberries. HortScience 16:794-795.

Finn, C., J. Hancock, and C. Heider. 1998. Notes on the strawberry of Ecuador: Ancient land races, the community of farmers and modern production. HortScience 33:583-587.

Hancock, J., C. Weebadde, and S. Serçe. 2008 Challenges faced by day-neutral strawberry breeders in the Continental climates of the Eastern USA and Canada. HortScience 43:1635-1636.

Hancock, J.F., P.W. Callow, A. Dale, J.J. Luby, C.E. Finn, S.C. Hokanson, and K.E. Hummer. 2001a. From the Andes to the Rockies: Native strawberry collection and utilization. HortScience 36:221-225.

Hancock, J.F., A. Dale, and J.J. Luby. 1993. Should we reconstitute Fragaria Xananassa? Acta Hort. 348:85-93.

Hancock, J.F., C.A. Finn, S.C. Hokanson, J.J. Luby, B.L. Goulart, K. Demchak, P.W. Callow, and K.E. Hummer. 2001b. A multistate comparison of native octoploid strawberries from North and South America. J. Amer. Soc. Hort. Sci. 126:579-586.

Hancock, J.F., C.E. Finn, J.J. Luby, A. Dale, P.W. Callow, and S. Serçe. 2010. Reconstruction of the strawberry, Fragaria Xananassa, using genotypes of $F$. virginiana and $F$. chiloensis. HortScience 45:1006-1013.

Hancock, J.F., S.C. Hokanson, C.E. Finn, and K.E. Hummer. 2000. Introducing a supercore collection of wild octoploid strawberries. Acta Hort. 567:77-79.

Hancock, J.F., J.J. Luby, A. Dale, P.W. Callow, S Serce, and A. El-Shiek. 2002. Utilizing wild Fragaria virginiana in strawberry cultivar development: Inheritance of photoperiod sensitivity, fruit size, gender, female fertility and disease resistance. Euphytica 126:177-184.

Hildreth, A.C. and L. Powers. 1940. The Rocky Mountain strawberry as a source of hardiness. Proc. Amer. Soc. Hort. Sci. 38:410-412.

Mookerjee, S., M.M. Mathey, C.E. Finn, Z. Zhang, and J.F. Hancock. 2013. Heat tolerance plays an important role in regulating remontant flowering in an $F_{1}$ population of octoploid strawberry (Fragaria Xananassa). J. Berry Res. 3:151-158.

Powers, L. 1954. Inheritance of period of blooming in progenies of strawberries. Proc. Amer. Soc. Hort. Sci. 64:293-298.

Serçe, S. and J.F. Hancock. 2005. The temperature and photoperiod regulation of flowering and runnering in the strawberries, Fragaria chiloensis, $F$. virginiana, and $F$. Xananassa. Scientia Hort. 103:167-177.

Stegmeir, T.L., C.E. Finn, R.M. Warner, and J.F. Hancock. 2010. Performance of an elite strawberry population derived from wild germplasm of Fragaria chiloensis and F. virginiana. HortScience 45:1140-1145. 